\title{
ERRATUM
}

Stephen P. Bird • Kyle M. Tarpenning Frank E. Marino

\section{Independent and combined effects of liquid carbohydrate/essential amino acid ingestion on hormonal and muscular adaptations following resistance training in untrained men}

Published online: 6 April 2006

(C) Springer-Verlag 2006

\section{Eur J Appl Physiol (2006) DOI 10.1007/s00421-005-}

0127-z

In Table 1, the variables should be glucose $(\mathrm{mmol} / \mathrm{l})$, insulin $(\mu \mathrm{lU} / \mathrm{ml})$ and cortisol $(\mathrm{nmol} / \mathrm{l})$. Data pertaining to testosterone and growth hormone should be disregarded.

The online version of the original article can be found at http:// dx.doi.org/10.1007/s00421-005-0127-z

S. P. Bird $(\bowtie) \cdot$ K. M. Tarpenning $\cdot$ F. E. Marino

School of Human Movement Studies, Charles Sturt University,

Allen House 2.13, Bathurst, NSW, Australia

E-mail: sbird@csu.edu.au

Tel.: + 612-6338-4155

Fax: + 612-6338-4065 